Andi Wahida : Kontribusi Pendapatan Wanita terhadap Ketahanan Pangan Rumahtangga pada Agroekosistem Sawah Tadah Hujan di kecamatan Ma'rang Kabupaten Pangkep/

\title{
KONSTRIBUSI PENDAPATAN WANITA TERHADAP KETAHANAN \\ PANGAN RUMAH TANGGA PADA AGROEKOSISTEM SAWAH TADAH HUJAN DI KECAMATAN MA'RANG KABUPATEN PANGKEP
}

\section{(Construction of Women's Revenue on Household Food Security in Rainfall Agrecosistems in Ma'rang District, Pangkep Regency)}

${ }^{1)}$ Andi Wahida, ${ }^{2)}$ Ida Rosada, ${ }^{2)}$ Mais Ilsan

\author{
1)Program Studi Magister Agroteknologi Pertanian Pascasarjana UMI \\ 2)Program Studi Agribisnis Fakultas Pertanian UMI \\ ${ }^{1)}$ E-mail andiwahida76@gmail.com \\ 2)Email ida.rosada@umi.ac.id \\ 2)Email mais.ilsan.umi@gmail.com
}

\begin{abstract}
Food security is an integrated system consisting of various subsystem. The main subsystem are food availability, food distribution and food consumption. The realization of good security is a synergy of the interactions of the three subsystem. The purpose of this study was to identify female household socioeconomic factors in rainfed lowland agroecosystems in Ma'rang sub-district, Pangkep district, review and analyze the contribution of women's income to household income, analyze the level of share of women's household food expenditure in rainfed lowland areas, analyze the level of female household food security in rainfed lowland agroecosystems. This research was conducted in July to September 2018. Sampling was carried out in census, namely 22 households. The results of the study showed that the contribution of women's income to household income was still very low at $15 \%$ of total household income, women's household food security in rainfed lowland areas is seen from the side of food expenditure, namely 63,64 percent of the share of food expenditure is in the category of food security ( $\leq$ $60 \%$ ) and as much as 36,36 percent of the share of food expenditure in the category is not food resistant $(\geq 60 \%)$, and the level of household food security is in the category of food security.
\end{abstract}

Keywords : Ketahanan Pangan; Pendapatan; Wanita; Agoekosistem

\section{PENDAHULUAN}

Pertanian masih menjadi sumber mata pencaharian mayoritas angkatan kerja di Indonesia. Pembangunan pertanian bertujuan untuk meningkatkan pendapatan dan taraf hidup petani, pertumbuhan kesempatan kerja dan berusaha, meningkatkan gizi dan luas lahan pertanian kabupaten pangkep ketahanan pangan rumah tangga, dan yaitu 16.732 hektar dengan total luas mengentaskan kemiskinan di pedesaan. panen padi pada tahun 2017 sebesar

Semua ini berkaitan erat dengan peran, 32.757 hektar (BPS, 2018). Kecamatan tugas, dan fungsi wanita di pedesaan.
Jumlah penduduk Kabupaten Pangkep pada tahun 2017 sekitar 329.791 jiwa yang tersebar di 4 kecamatan pulau dan 9 kecamatan daratan. Sebagian besar penduduknya bergerak dalam bidang pertanian yaitu sekitar 39.060 rumah tangga bergerak di sektor pertanian. Total 
Ma'rang memiliki total luas lahan semakin besar pula jumlah tanggungan sebanyak 1.456 hektar.

Terbatasnya kemampuan petani keluarga yang harus dipenuhi oleh kepala keluarga.

sawah tadah hujan untuk meningkatkan

Oleh karena itu penelitian ini pendapatan guna memenuhi kebutuhan bertujuan untuk mengidentifikasi faktor hidup atau kebutuhan pokok keluarganya, sosial ekonomi wanita pada rumahtangga sehingga memaksa mereka untuk mencari upaya lain. Salah satu upayanya adalah dengan melakukan pekerjaan lain di luar usaha pertanian tersebut. Pekerjaan lain yang dilakukan di luar bertani diharapkan mampu untuk meningkatkan pendapatan guna memenuhi kebutuhan hidup keluarganya. Akan tetapi para petani sawah tadah hujan memiliki keterampilan yang minim, sehingga tidak mudah bagi mereka untuk mendapatkan pekerjaan lain yang disebabkan oleh karena terbatasnya pendidikan yang mereka dapatkan di bangku sekolah. Selain itu, pekerjaan lain yang ditekuni seringkali tidak memberikan sumbangsih yang besar dalam upaya pemenuhan kebutuhan hidup keluarganya sehari-hari. Sehingga keluarga petani sawah tadah hujan akan tetap mengalami kesulitan dalam upaya memenuhi kebutuhan keluarganya. Upaya pemenuhan kebutuhan keluarga bertambah sulit bila jumlah anak yang agroekosistem sawah tadah hujan di Kecamatan Ma'rang Kabupaten Pangkep, mengkaji dan menganalisis konstribusi pendapatan wanita terhadap pendapatan rumahtangga, menganalisis tingkat Pangsa Pengeluaran Pangan rumahtangga pada lahan sawah tadah hujan dan menganalisis tingkat ketahanan pangan rumahtangga pada agroekosistem sawah tadah hujan. Hasil dari penelitian ini diharapkan dapat memberi masukan bagi pemerintah tentang kondisi sosial ekonomi wanita dan kondisi ketahanan pangan keluarga petani khususnya petani lahan sawah tadah hujan.

\section{METODEPENELITIAN}

Penelitian ini dilaksanakan di Kecamatan Marang Kabupaten Pangkep yaitu di Kelurahan Ma'rang dan Kelurahan Attangsalo dengan jumlah sampel yaitu sebanyak 22 responden.

1. Metode Analisis Data

Analisis data yang digunakan adalah : jumlah anak yang dimiliki maka akan 
I. Untuk menguji hipotesis pertama pendapatan dengan rumus : digunakan analisis konstribusi

$$
\text { Analisis konstribusi }=\frac{\Sigma \text { Pendapatan Wanita Tani }}{\Sigma \text { total pendapatan rumahtangga }} \times 100 \%
$$

Penentuan besarnya kontribusi c. Jika kontribusi pendapatan wanita pendapatan wanita tani terhadap total 50\%-75\% pendapatan rumah tangga pendapatan rumah tangga digunakan petani. dikategorikan tinggi

kriteria yang dikemukakan oleh Widodo d. Jika kontribusi pendapatan wanita > (2001) dalam Luhukay (2009), sebagai $75 \%$ pendapatan rumah tangga petani berikut : dikategorikan sangat tinggi.

a. Jika kontribusi pendapatan wanita $<$

II. Untuk menganalisis tingkat Pangsa $25 \%$ pendapatan rumah tangga petani, dikategorikan sangat rendah Pengeluaran Pangan rumahtangga wanita tani dan Tingkat Ketahanan

b. Jika kontribusi pendapatan wanita Pangan rumahtangga digunakan rumus: $25 \%$ - $49 \%$ pendapatan rumah tangga petani, dikategorikan rendah;

$$
\mathrm{PPP}=\frac{\mathrm{FE}}{\mathrm{TE}} \times 100 \%
$$

Dimana :

$\mathrm{PPP}=$ pangsa pengeluaran pangan $(\%)$

$\mathrm{FE}=$ pengeluaran untuk belanja tahan pangan, kebutuhan pangan (Rp/bulan) - Jika pangsa pengeluaran pangan lebih $\mathrm{TE}=$ total pengeluaran kebutuhan atau sama dengan $60 \%$ maka rumah rumahtangga (Rp/bulan)

Dimana :
-Jika pangsa pengeluaran pangan kurang dari $60 \%$ maka rumah tangga tersebut tangga tersebut tidak tahan pangan (Maxwell et al., 2000). 
Andi Wahida : Kontribusi Pendapatan Wanita terhadap Ketahanan Pangan Rumahtangga pada Agroekosistem Sawah Tadah Hujan di kecamatan Ma'rang Kabupaten Pangkep/

\section{HASIL DAN PEMBAHASAN}

1. Umur

Tabel 1 Kategori Usia Responden Wanita di Kecamatan Ma'rang Kabupaten Pangkep

\begin{tabular}{cccc}
\hline \hline \multirow{2}{*}{ No } & Interval Usia & Jumlah Responden & Persentase \\
\cline { 2 - 4 } & (Tahun) & (orang) & $(\%)$ \\
\hline \hline 1 & $40-45$ & 15 & 68,18 \\
2 & $46-51$ & 5 & 22,73 \\
3 & $52-57$ & 2 & 9,09 \\
\hline \hline \multicolumn{5}{c}{ JUMLAH } & 22 & 100,00 \\
\hline \hline Umur Maksimum & 55 & \\
Umur Minimum & & 40 & \\
Umur Rata - rata & & 44,95 & \\
\hline \hline
\end{tabular}

Secara umum, rata - rata umur responden wanita antara 40 - 45 tahun responden wanita tani masih berada pada sebanyak 15 responden atau $6818 \%$, kelompok usia produktif untuk bekerja. frekuensi umur tertinggi antara 52 - 57 Artinya, secara fisik wanita responden tahun sebanyak 2 responden atau 9,09\%, masih memiliki potensi yang besar untuk dan umur antara $46-51$ tahun sebanyak 5 menghasilkan barang dan jasa. Di responden atau 22,73\%. Kecamatan Ma'rang rata-rata umur

\section{Pendidikan}

Tabel 2 Tingkat Pendidikan Wanita Responden di Kecamatan Ma’rang, 2018

\begin{tabular}{lccc}
\hline \hline \multicolumn{1}{c}{ Tingkat Pendidikan } & Jumlah (orang) & Persentase (\%) \\
\hline \hline Tidak bersekolah & 0 & 0,00 \\
SD & 7 & 31,82 \\
SMP & 11 & 50,00 \\
SMA & 4 & 18,18 \\
Sarjana & 0 & & 0,00 \\
\hline \hline J U M L A H & 22 & & 100,00 \\
\hline \hline Tingkat Pendidikan Maksimum & & SMA & \\
Tingkat Pendidikan Minimum & & SD & \\
Rata-rata tingkat pendidikan & & SMP & \\
\hline \hline
\end{tabular}

Dari Tabel diatas dapat dilihat tingkat pendidikan minimum, dan bahwa sebanyak 7 orang $(31,82 \%)$ responden dengan tingkat pendidikan responden dengan tingkat pendidikan SMP sebanyak 11 orang (50\%) yang hanya sampai tingkat SD yang merupakan merupakan rata-rata tingkat pendidikan 
Andi Wahida : Kontribusi Pendapatan Wanita terhadap Ketahanan Pangan Rumahtangga pada Agroekosistem Sawah Tadah Hujan di kecamatan Ma'rang Kabupaten Pangkep/

responden, sedangkan responden dengan orang (18,18\%) yang merupakan tingkat tingkat pendidikan SMA sebanyak 4 pendidikan maksimum

3. Jumlah Anggota Keluarga

Tabel 3 Jumlah Anggota Keluarga Responden di Kecamatan Ma’rang Kabupaten Pangkep, 2018

\begin{tabular}{|c|c|c|c|}
\hline No & $\begin{array}{l}\text { Jumlah Anggota } \\
\text { Keluarga (orang) } \\
\end{array}$ & $\begin{array}{c}\text { Jumlah } \\
\text { Responden } \\
\end{array}$ & $\%$ \\
\hline 1 & 3 & 1 & 4,55 \\
\hline 2 & 4 & 5 & 22,73 \\
\hline 3 & 5 & 11 & 50,00 \\
\hline \multirow[t]{2}{*}{4} & 6 & 5 & 22,73 \\
\hline & $\mathrm{MLAH}$ & 22 & 100,00 \\
\hline \multicolumn{2}{|c|}{ Jumlah anggota keluarga maksimum } & 6 & \\
\hline \multicolumn{2}{|c|}{ Jumlah anggota keluarga minimum } & 3 & \\
\hline \multicolumn{2}{|c|}{ Rata-rata jumlah anggota keluarga } & 4,9 & \\
\hline
\end{tabular}

Dari tabel dapat dilihat bahwa anggota keluarga maksimum, responden responden dengan jumlah anggota dengan jumlah anggota keluarga 4 orang keluarga terbanyak yaitu 5 orang sebanyak 5 responden $(22,73 \%)$, dan sebanyak 11 responden (50\%), sedangkan jumlah responden yang memiliki jumlah responden dengan jumlah anggota anggota keluarga sebanyak 3 orang yaitu keluarga 6 orang sebanyak 5 responden satu responden yang merupakan jumlah $(22,73 \%)$ yang merupakan jumlah anggota keluarga minimum.

\section{Pekerjaan Wanita}

Tabel 4 Jenis Pekerjaan Wanita Responen di Kecamatan Ma’rang, 2018

\begin{tabular}{clcr}
\hline \hline \multirow{2}{*}{ No } & \multirow{2}{*}{ Jenis Pekerjaan } & Jumlah & Persentase \\
$(\%)$ & \\
\hline \hline 1 & Jual bahan campuran & 21 & 95,45 \\
2 & Wiraswasta & 1 & 4,55 \\
\hline \hline
\end{tabular}

Dari tabel dapat dilihat bahwa jenis dimaksud adalah bahan untuk kebutuhan pekerjaan yang dilakukan oleh wanita sehari-hari seperti gula, teh, kopi, biskuit yaitu jual bahan campuran dan dan minuman. Penjualan bahan campuran wiraswasta. Bahan campuran yang ini dilakukan di bawah kolong rumah atau 
dibuatkan kios di depan rumah yang oleh

masyarakat setempat disebut gadde.

\section{Pengalaman Berusaha}

Tabel 5 Pengalaman Berusaha Wanita Responden di Kecamatan Ma'rang, 2018

\begin{tabular}{cccr}
\hline \hline No & $\begin{array}{c}\text { Pengalaman } \\
\text { Berusaha } \\
\text { (Tahun) }\end{array}$ & $\begin{array}{c}\text { Jumlah } \\
\text { Responden }\end{array}$ & $\begin{array}{c}\text { Persentase } \\
(\%) ~\end{array}$ \\
\hline \hline 1 & 3 & 1 & 4,55 \\
2 & 4 & 5 & 22,73 \\
3 & 5 & 8 & 36,36 \\
4 & 6 & 8 & 36,36 \\
\hline \hline
\end{tabular}

Dari tabel dapat dilihat bahwa berusaha selama 3 tahun sebanyak 1 pengalaman berusaha wanita responden responden $(4,55 \%)$. Ini menunjukkan selama 5 tahun sebanyak 8 responden bahwa pekerjaan yang dilakukan oleh $(36,36 \%)$, wanita dengan pengalaman 6 wanita membantu pendapatan tahun sebanyak 8 responden $(36,36 \%)$ rumahtangga sehingga wanita tani dan pengalaman berusaha wanita responden bertahan untuk melanjutkan responden selama 4 tahun sebanyak 5 usahanya. responden $(22,73 \%)$ sedangkan yang baru

\section{Pendapatan Wanita}

Tabel 6 Pendapatan Wanita Responden di Kecamatan Ma’rang, 2018

\begin{tabular}{ccccr}
\hline \hline No & $\begin{array}{c}\text { Pendapatan } \\
(\text { Rp/Bulan })\end{array}$ & $\begin{array}{c}\text { Jumlah } \\
\text { Responden }\end{array}$ & $\begin{array}{c}\text { Persentase } \\
(\%)\end{array}$ & \\
\hline \hline 1 & $325.000-433.333$ & 15 & & 68,18 \\
2 & $433.334-541.667$ & 6 & & 27,27 \\
3 & $541.668-650.000$ & 1 & & 100,00 \\
\hline \hline & JUMLAH & 22 & & \\
\hline \hline & Pendapatan Maksimum & Rp. 650.000 & \\
& Pendapatan Minimum & Rp. 325.000 & & \\
& Pendapatan Rata - rata & Rp. 418.561 & & \\
\hline \hline
\end{tabular}


Dari Tabel dapat dilihat bahwa (27,27 \%) dan untuk penghasilan Rp. pendapatan rata-rata wanita responden 541.668 - Rp. 650.000 sebanyak 1 yang terbanyak yaitu antara Rp. $325.000-$ responden $\quad(4,55 \quad \%)$, Pendapatan Rp. 433.333,- atau mencapai 68,18 \%. maksimum wanita responden yaitu Rp. Sedangkan untuk penghasilan Rp. 433.334 650.000,- dan pendapatan minimum Rp. - Rp. 541.667 sebanyak 6 responden 325.000,-

\section{Pendapatan Rumahtangga}

Tabel 7 Sumber Pendapatan dan Besarnya Pendapatan Rumahtangga Responden di Kecamatan Ma'rang, 2018

\begin{tabular}{|c|c|}
\hline Uraian & $\begin{array}{c}\text { Pendapatan } \\
\text { (Rp/Bulan) }\end{array}$ \\
\hline I. Pendapatan Suami & 2.320 .075 \\
\hline - Usaha Tani & 2.231 .439 \\
\hline - Luar Usaha Tani & 88.636 \\
\hline II. Pendapatan Istri & 409.469 \\
\hline - Usaha Tani & 36.742 \\
\hline - Luar Usaha Tani & 372.727 \\
\hline $\begin{array}{ll}\text { JUMLAH } \\
\end{array}$ & 2.729 .544 \\
\hline
\end{tabular}

Pendapatan adalah jumlah tani hortikultura (kacang hijau, kacang penghasilan riil dari seluruh anggota tanah dan ubi jalar) serta pendapatan dari rumahtangga yang disumbangkan untuk luar usaha tani yaitu sebagai tukang bentor memenuhi kebutuhan bersama maupun dan peternak sapi. Dan untuk pendapatan perseorangan dalam rumahtangga. Rata - istri rata - rata sebesar Rp. 409.469,- yang rata pendapatan suami responden yang diperoleh dari pendapatan usaha tani yaitu diperoleh pada saat penelitian yaitu bekerja sebagai pencabut benih dan sebesar Rp. 2.320.075 yang terdiri dari menanam padi dan juga menjual pendapatan dari usaha tani padi dan usaha campuran.

8. Luas Lahan yang dimiliki

Tabel 8 Luas Lahan yang dimiliki oleh Petani Responden di Kecamatan Ma'rang

\begin{tabular}{cccr}
\hline \hline No & $\begin{array}{c}\text { Luas Lahan } \\
(\text { Ha })\end{array}$ & $\begin{array}{c}\text { Jumlah } \\
\text { Responden }\end{array}$ & $\begin{array}{c}\text { Persentase } \\
(\%)\end{array}$ \\
\hline \hline 1 & 0,5 & 3 & 13,64 \\
2 & 1 & 18 & 81,82 \\
3 & 1,5 & 1 & 4,55 \\
\hline \hline
\end{tabular}


Andi Wahida : Kontribusi Pendapatan Wanita terhadap Ketahanan Pangan Rumahtangga pada Agroekosistem Sawah Tadah Hujan di kecamatan Ma'rang Kabupaten Pangkep/

\begin{tabular}{lcc}
\hline \multicolumn{1}{c}{ JUMLAH } & 22 & 100,00 \\
\hline \hline Luas lahan maksimum & 1,5 & \\
Luas lahan minimum & 0,5 & \\
Rata-rata luas lahan & 0,95 & \\
\hline \hline
\end{tabular}

Luas lahan yang dimiliki oleh petani responden dengan luas lahan 0,5 ha responden merupakan milik sendiri, sebanyak 3 responden 13,64\%) jumlah responden dengan luas lahan 1 ha sedangkan hanya satu responden yang sebanyak 18 responden $(81,82 \%)$, memiliki luas lahan 1,5 ha.

Tabel 9 Jumlah Pendapatan Rumahtangga Responden di Kecamatan Ma’rang, 2018

\begin{tabular}{cccc}
\hline \hline No & $\begin{array}{c}\text { Pendapatan } \\
(\text { Rp/bulan })\end{array}$ & $\begin{array}{c}\text { Jumlah } \\
\text { Responden }\end{array}$ & $\begin{array}{c}\text { Persentase } \\
(\%)\end{array}$ \\
\hline \hline 1 & $1.958 .333-2.444 .444$ & 2 & 9,09 \\
2 & $2.444 .445-2.930 .556$ & 15 & 68,18 \\
3 & $2.930 .557-3.416 .668$ & 5 & 22,73 \\
\hline \hline \multicolumn{5}{c}{ JUMLAH } & 22 & 100,00 \\
Pendapatan rumahtangga maksimum & 3.416 .667 & \\
Pendapatan rumahtangga minimun & 1.958 .333 & \\
Rata-rata pendapatan rumahtangga & 2.996 .844 & \\
\hline \hline
\end{tabular}

9. Pekerjaan Sampingan Suami

Tabel 10 Pekerjaan Sampingan Suami Responden di Kecamatan Ma’rang, 2018

\begin{tabular}{|c|c|c|c|}
\hline No & $\begin{array}{c}\text { Pekerjaan } \\
\text { Alternatif } \\
\end{array}$ & $\begin{array}{c}\text { Jumlah } \\
\text { Responden } \\
\end{array}$ & $\begin{array}{c}\text { Persentase } \\
(\%) \\
\end{array}$ \\
\hline 1 & Ada & " & 18,18 \\
\hline 2 & Tidak ada & 18 & 81,82 \\
\hline \multicolumn{2}{|c|}{ JUMLAH } & 22 & 100,00 \\
\hline
\end{tabular}

Dari tabel dapat dilihat bahwa petani sebagai penghasilan utama untuk responden rata-rata tidak memiliki keluarganya dan hanya 4 responden pekerjaan lain selain bertani yaitu $(18,18 \%)$ yang memiliki pekerjaan selain sebanyak 18 responden hanya bertani bertani.

10. Konstribusi Pendapatan Wanita terhadap Pendapatan Rumahtangga

Tabel 11 Konstribusi Pendapatan Wanita terhadap Pendapatan Rumahtangga

\begin{tabular}{lcc}
\hline \hline \multirow{2}{*}{ Sumber Pendapatan } & Nilai Rata-rata & Konstribusi \\
& $(\mathrm{Rp} / \mathrm{bulan})$ & $(\%)$ \\
\hline \hline
\end{tabular}


Andi Wahida : Kontribusi Pendapatan Wanita terhadap Ketahanan Pangan Rumahtangga pada Agroekosistem Sawah Tadah Hujan di kecamatan Ma'rang Kabupaten Pangkep/

\begin{tabular}{llr}
\hline \hline - Suami & 2.320 .076 & 85,00 \\
- Istri & 409.470 & 15,00 \\
\hline \hline Total Pendapatan Rumahtangga & 2.729 .546 & 100,00 \\
\hline \hline
\end{tabular}

Dari Tabel dapat dilihat bahwa rata-rata pendapatan responden dari hasil

konstribusi pendapatan wanita tani masih usahanya sebesar Rp. 409.470, tergolong sangat rendah karena masih konstribusi terhadap pendapatan berada dibawah $25 \%$ yaitu $(15,47 \%)$. rumahtangganya memang tidak terlalu Meskipun konstribusi pendapatan wanita besar, namun kegiatan ekonomi responden tani masih rendah tetapi pendapatan yang dirasakan berperan cukup penting dalam diperoleh dapat membantu menyumbang menambah pendapatan keluarga. pendapatan keluarga. Apabila dilihat dari

\section{Pangsa Pengeluaran Pangan (PPP)}

Tabel 12 Jenis Pengeluaran Rumahtangga Responden di Kecamatan Ma'rang, 2018

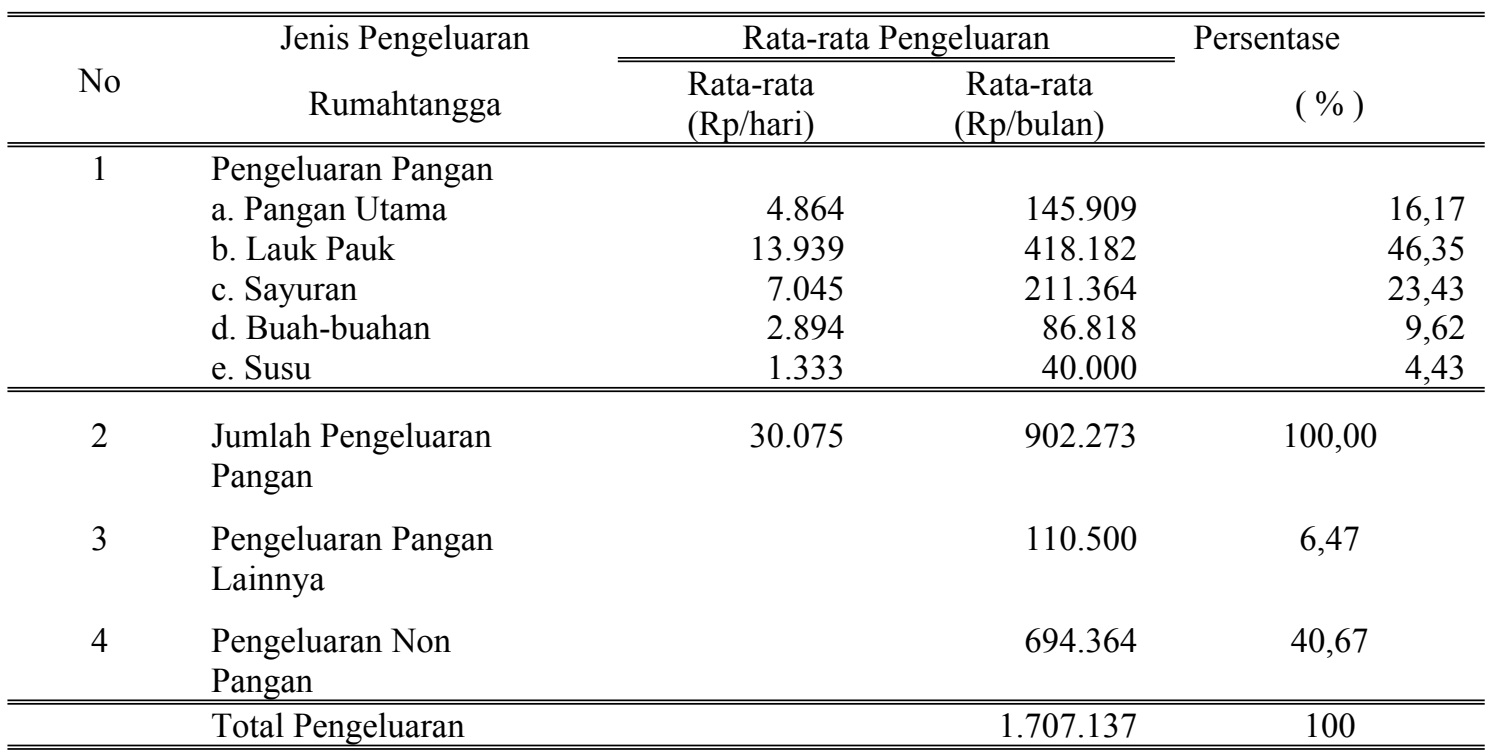

Berdasarkan Tabel, dapat diketahui bahwa pengeluaran rumahtangga responden terdiri atas pengeluaran pangan (Pangan utama, lauk pauk, sayuran, buahbuahan dan susu), Pengeluaran pangan lainnya (gula, teh, kopi dan minyak goreng), pengeluaran non pangan (bensin, gas, listrik, pulsa, uang saku dan biaya sosial). Dari hasil penelitian diketahui bahwa rata-rata pengeluaran terbanyak responden adalah untuk pengeluaran pangan. Dan dapat dilihat bahwa terdapat saving sebesar Rp. 1.022.407,- 
Andi Wahida : Kontribusi Pendapatan Wanita terhadap Ketahanan Pangan Rumahtangga pada Agroekosistem Sawah Tadah Hujan di kecamatan Ma'rang Kabupaten Pangkep/

Untuk mengetahui distribusi pangsa tani dapat dilihat pada tabel berikut : pengeluaran pangan rumahtangga wanita

Tabel 13 Distribusi Pangsa Pengeluaran Pangan Rumahtangga Wanita di Kecamatan Ma'rang, 2018

\begin{tabular}{|c|c|c|c|}
\hline Kategori & $\begin{array}{c}\text { Pangsa Pengeluaran } \\
\text { Pangan (PPP) } \\
\end{array}$ & $\begin{array}{c}\text { Jumlah } \\
\text { Responden } \\
\end{array}$ & $\begin{array}{c}\text { Persentase } \\
(\%) \\
\end{array}$ \\
\hline Tahan Pangan & $<60 \%$ & 14 & 63,64 \\
\hline Tidak Tahan Pangan & $>60 \%$ & 8 & 36,36 \\
\hline & & 22 & 100,00 \\
\hline
\end{tabular}

Berdasarkan Tabel diatas, dapat maka kelompok rumah tangga tersebut diketahui bahwa sebagian besar merupakan golongan yang relatif rumahtangga wanita tani termasuk dalam sejahtera. pangsa pengeluaran pangan dengan kategori tahan pangan sebanyak 63,64 1. Kondisi sosial ekonomi rumahtangga persen atau sebanyak 14 responden dan wanita pada agroekosistem sawah tadah hujan adalah dominan berada pada kisaran umur 45 tahun - 49 tahun; tingkat pendidikan yang terbanyak adalah SMP; jumlah anggota keluarga rata-rata 5 orang; pengalaman berusaha rata-rata 5 - 6 tahun. Kondisi ekonomi rumahtangga wanita pada agroekosistem sawah tadah hujan adalah : rata-rata pendapatan rumahtangga adalah Rp. 2.729.545,; rata-rata pendapatan wanita sebesar Rp. apabila persentase atau pangsa pengeluaran pangan tinggi $(>60 \%$ pengeluaran total) maka kelompok rumah tangga tersebut merupakan golongan yang relatif kurang sejahtera, dan apabila persentase atau pangsa pengeluaran pangan rendah $(<60 \%$ pengeluaran total) 418.561/bulan ; Luas lahan yang dimiliki rata-rata 1 ha; dan sebagian besar suami tidak memiliki pekerjaan sampingan selain dibidang pertanian.

2. Konstribusi pendapatan wanita terhadap pendapatan rumahtangga 
masih tergolong sangat rendah yaitu $15 \%$ dari total pendapatan rumahtangga.

3. Ketahanan pangan rumahtangga wanita pada lahan sawah tadah hujan dilihat dari sisi Pangsa Pengeluaran Pangan (PPP) yaitu sebanyak 63,64 persen rumahtangga Pangsa Pengeluaran Pangannya masuk dalam kategori tahan pangan $(\leq 60 \%)$ dan sebanyak 36,36 persen Pangsa Pengeluaran Pangannya masuk dalam kategori tidak tahan pangan ( $\geq 60 \%)$.

4. Tingkat ketahanan pangan rumah tangga berada pada kategori tahan pangan

\section{DAFTAR PUSTAKA}

Cahyono, S. Andy. 1998. Karakteristik Sosial Ekonomi yang Mempengaruhi Pendapatan Rumah Tangga Penyadap Getah Pinus di Desa Somagede, Kebumen, Jawa Tengah. Jurnal UGM.

Elizabeth, R. 2007b. Pengarusutamaan gender melalui managemen sumberdaya keluarga dan diversifikasi pendapatan rumah tangga petani di pedesaan: antara harapan dan kenyataan. Makalah Lokakarya Pengarusutamaan Gender. FEMA IPB Bogor bekerjasama dengan Kementrian Pemberdayaan Perempuan RI.

FAO. 1994. Women, Agriculture and Rural Development; A Synthesis Report of the Africa Region. Rome
Hardiansyah. 2007. Review Faktor Determinan Keragaman Konsumsi Pangan. JurnalGizi dan Pangan. Juli 2007 2(2): 55 -74.

Idarosada, Nurliani, Farizah D. Amran 2017. Faktor Penghambat dan Faktor Pendorong Perempuan Berperan Ganda (Studi Perempuan Pekerja Informal di Kecamatan Mandalle, Kabupaten Pangkep, Provinsi Sulawesi Selatan. Jurnal Ecosystem Unibos vol 17 no. 3. 2017.

Idarosada, Nurliani. 2018. Pola Konsumsi Pangan Rumahtangga Petani pada Agroekosistem Persawahan. Jurnal Ekosistem vol 18 no. 3. SeptemberDesember 2018

Krisnamuthi,

B. 2006 . Penganekaragaman pangan sebuah kebutuhan yang mendesak. Makalah seminar nasional diversifikasi untuk mendukung ketahanan pangan.

Luhukay, 2009. Analisis Pengolahan Gula Aren Dalam Meningkatkan Kesejahteraan Petani di Desa Tuhaha, Kabupaten Maluku Tengah. Tesis, UGM

Maxwell, D., Levin, M. A. Klemeseu, M. Rull, S. Morris and C. Aliadeke. 2000. Urban Livelihoods and Food Nutrition security in Greater accra, Ghana. IFPRI in Collaborative with Noguchi Memorial Research and World Health Organization. Research Report No. 112, Washington D.C.

Mulyani, Altri, Alpha Nadeira Mandamdari. 2012. Peran Wanita Dalam Mewujudkan Ketahanan Pangan Rumah Tangga di Kabupaten Banyumas (Studi Kasus di Kecamatan Cilongok). Jurnal SEPA 8(2):51-182

Nurmanaf, A. R. 2006. Peranan sektor luar pertanian terhadap kesempatan 
dan pendapatan di pedesaan berbasis lahan kering.Jurnal SOCAvol 8. no3. November 2008, hal 318-322.

Sajogyo, P. 1994. Peranan Wanita dalam Perkembangan Ekonomi. Obor. Jakarta.

Sajogjo, 2003. Peranan Wanita Dalam Perkembangan Masyarakat Desa Rajawali Press, Jakarta. 
Sayogyo, T. 1997. Garis Kemiskinan dan Kebutuhan Minimum Pangan. LPSB-IPB. Bogor. $299 \mathrm{hlm}$

Suharyono dan Moh. Amien. 1994. Pengantar Filsafat Geografi. Departemen Pendidikan dan Budaya. Jakarta

Sukiyono, et all. 2008. Status Wanita dan Ketahanan Pangan Rumah Tangga Nelayan dan Petani Padi di Kabupaten Muko-Muko Provinsi Bengkulu. JurnalAgro Ekonomi. Volume 26 no. 2Oktober 2008: 191 $-207$.
Toha, H.M., dan D. Juanda. 1991. Pola tanam tanaman pangan di lahan kering dan sawah tadah hujan (Kasus Desa Ngumbul dan Sonokulon, Kabupaten Blora). Prosiding Seminar Hasil Penelitian Pertanian Lahan Kering dan Konservasi Tanah di Lahan Sedimen dan Vulkanik DAS Bagian Hulu. Proyek penelitian penyelamatan hutan tanah dan air. Badan Penelitian dan Pengembangan Pertanian. p. 37-49. 